\section{NOTES FOR A NETWORKED BIOGRAPHY: The P. G. T. Black Collection of Oceanic Things}

\section{Robert J. Foster \\ UNIVERSITY OF ROCHESTER}

\section{ABSTRACT}

In 1938, the Buffalo Museum of Science acquired some 62 hundred objects collected between 1886 and 1916 by and for P. G. Black, a branch inspector for Burns, Philp \& Company Ltd., the famous Sydney-based mercantile and shipping firm. Despite the collection's size, breadth, and significance as a product of the colonial encounter in northern Australia and Melanesia, its history is still largely unrecorded. This article begins to trace the social life of the collection by narrating a formative moment in its biography: the period of Burns, Philp's expansion into the southwest Pacific during which Black assembled the collection. It also identifies two other moments: the years after Black's death in 1921 when the overseas purchase of the collection was decried in Australian newspapers and the years after the collection came to Buffalo when objects were loaned for display at American fine arts museums, including the Museum of Modern Art in New York. At these particular biographical moments, objects in the collection were differently construed as native curios and ethnological specimens, national patrimony, and primitive art. This article advances a trend of recent scholarship in anthropology and museology by foregrounding the historical circumstances and social relations that condition the appropriation of objects. [Buffalo Museum of Science, P. G. T. Black Collection, Oceania, Australian Museum, art/artifact, object biography, national patrimony]

\section{The P. G. T. Black Collection}

In January 1946, the Museum of Modern Art in New York opened the new year with Arts of the South Seas, a landmark exhibition of objects from the Pacific Islands and Aboriginal Australia. It was not, however, the first time that Oceanic things had been publicly displayed in an American metropolitan fine arts museum. In the autumn of 1945, for example, the City Art Museum of St. Louis mounted a special exhibition intended to affirm the "validity and beauty" of objects produced by Pacific Islanders (Nagel 1945). Six years earlier, Harvard scholar of Asian art Langdon Warner included a selection of
Oceanic things in the Pacific Cultures exhibit sponsored by the Department of Fine Arts (Pacific Cultures Division) of the 1939 Golden Gate International Exposition in San Francisco (Warner 1939).

In each of these three early art exhibits of Oceanic things, objects on loan from the Buffalo Museum of Science were on display. These objects - among other things, a Trobriand painted shield (Figure 1), an obsidian dagger from the Admiralty Islands (Figure 2), and a canoe prow ornament and shell plaque from the Western Solomon Islands - comprised but a small part of the P. G. T. Black Collection, acquired in 1938 by the president of the Buffalo Museum of Science, Chauncey J. Hamlin. Hamlin purchased the collection of more than 6,200 objects from Black's son, Wulric (P. T. W. Black), for US $\$ 6,000$ with the help of a grant from the Carnegie Corporation (Hamlin 1938).

Although Hamlin intended to exhibit objects from the Black Collection as examples of "primitive art," the collection itself predates this idea. It was assembled between approximately 1886 and 1916 by and for Percy George Theodore Black, an accountant and later chief branch inspector for Burns, Philp \& Company Ltd., or "BP" (Figure 3). Born in London in 1861 and raised in Vienna by his widowed mother,

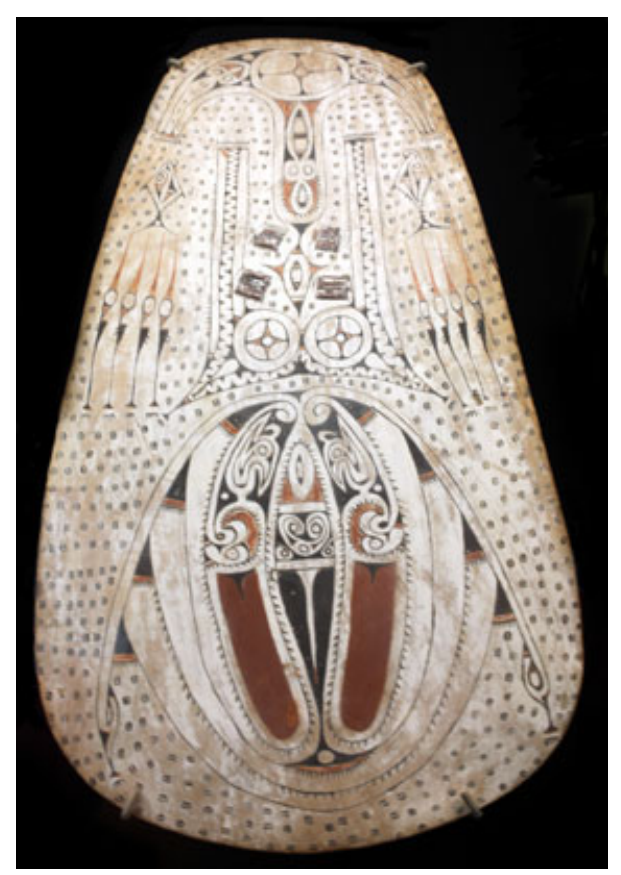

Figure 1. Painted shield, Trobriand Islands, Papua New Guinea. (Courtesy Buffalo Museum of Science, C8163.) 


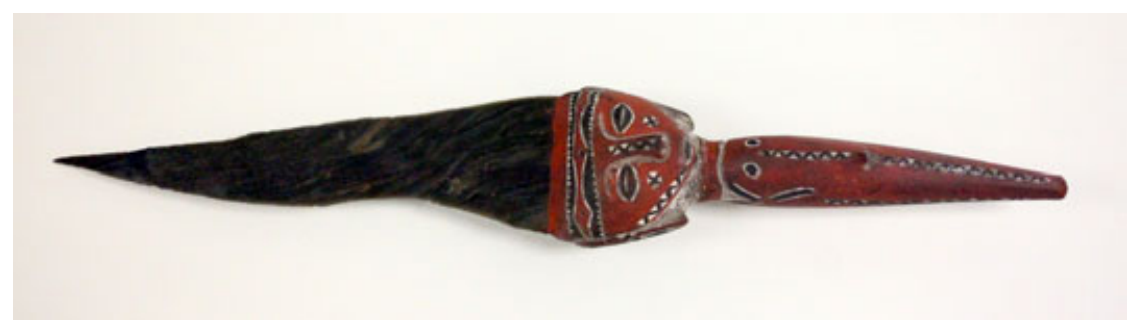

Figure 2. Dagger with obsidian blade, Admiralty Islands (Manus Province), Papua New Guinea. (Courtesy Buffalo Museum of Science, C10764.)

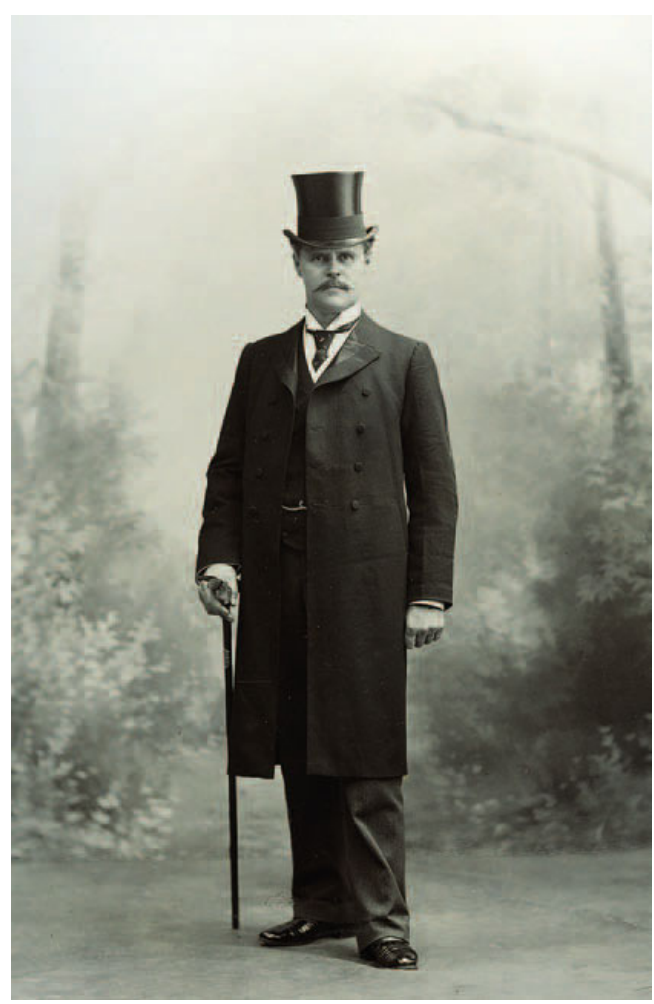

Figure 3. P. G. T. Black (1861-1921). Studio picture taken in Vienna, 1901. (Courtesy Buffalo Museum of Science.)

who worked as a governess, P. G. Black immigrated to Australia in $1883 .^{1} \mathrm{He}$ eventually found employment with BP and over his career rose to the position of general manager and director of BP. Both his son, Wulric, and Wulric's son, Charles, also became directors of the firm.

In the 1880s and 1890s, BP was an expanding Australian mercantile company headquartered in Sydney. Its shipping operations delivered passengers and cargo to the north of Australia, British New Guinea (later the Territory of Papua administered by Australia), and the New Hebrides, among other Pacific destinations (Figure 4). Objects from what is today Papua New Guinea, especially Milne Bay Province (the Massim region), Oro Province, and the Port
Moresby areas, form the bulk of Black's collection, which also includes a small number of objects from Polynesia and Micronesia. The collection's geographical scope reflects BP's trade routes. For example, most of the approximately four hundred and seventy Aboriginal Australian objects in the collection come from northern Queensland, where Black made several business trips as a branch inspector; conversely, relatively few objects come from what was then German New Guinea-none at all from the Sepik River area-where BP had few operations. The collection is one of the oldest and largest assemblages of Oceanic material culture in North America put together by a single person, comparable to the well-known collections at Chicago's Field Museum made by A. W. F. Fuller and A. B. Lewis (see Force and Force 1971; Welsch 1998). ${ }^{2}$

Despite the Black Collection's size, breadth, and significance as a product of the colonial encounter in northern Australia and Melanesia, its history is still largely unrecorded. An important attempt to rectify this situation was undertaken in 1995 by Kevin Smith, then a curator of anthropology at the Buffalo Museum of Science (see Smith 1995; Vogel 1995). Smith discovered the existence of family papers in the possession of P. G. Black's grandson, Charles Black, a resident of the San Francisco Bay area. These papers (stored in P. G. Black's original metal steamer trunks) include itineraries of Black's inspection trips, an address book, memoranda, and other miscellaneous documents that offer clues about the circumstances in which P. G. Black assembled his collection. Smith also acquired a copy of a 1901 catalogue of Black's collection from the Australian Museum in Sydney. Comparison with the 1914 catalogue and the 1938 inventory already at the Buffalo Museum of Science makes it possible to determine roughly when an object came into the collection (e.g., before or after 1901). The catalogues, as well as many of Black's 


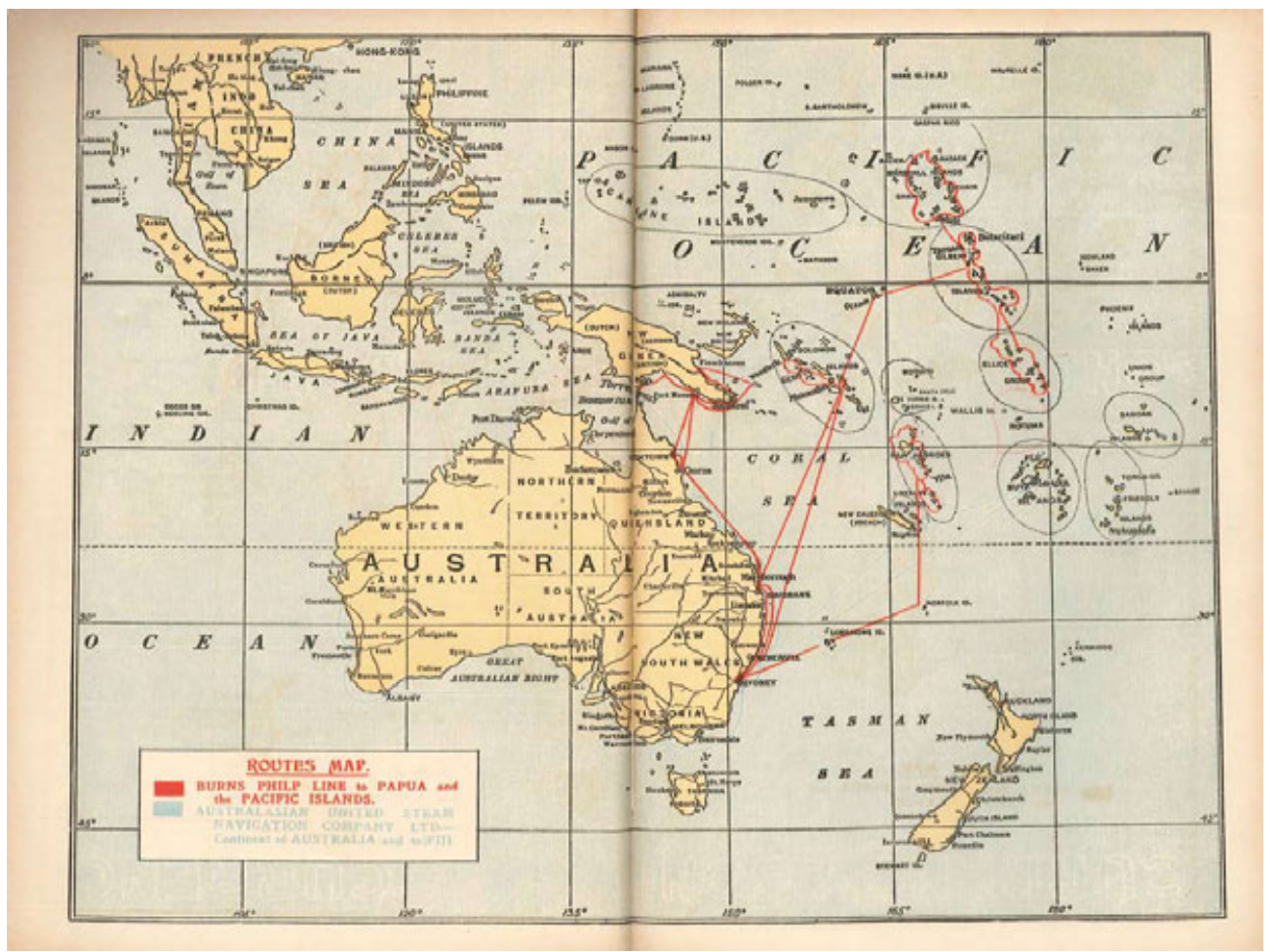

Figure 4. Burns, Philp Routes Map, 1914. Australia, Papua, and the Pacific Islands. (Source: Burns, Philp and Company 1914.)

handwritten labels, ascribe provenance to objects (e.g., "Bamu River, West B.N.G" or "Malekula, N.H."); they do not, however, list a price or monetary value for objects. My immediate goal here is to use these resources to reconstruct the extended moment during which the Black Collection took shape, focusing in particular on the trade in so-called curios in western Melanesia around the turn of the 20th century.

In addition, I will briefly discuss a second moment in the life of the collection: the years after Black's death in 1921 when the overseas purchase of the collection was decried in Australian newspapers. I have elsewhere discussed a third moment, the period signified by the 1946 display of several objects from the collection at the Museum of Modern Art in New York (Foster 2012). At each of these three moments, objects in the collection and the collection as a whole were differently construed by various parties as native curios, ethnological specimens, national patrimony, and primitive art.

My second goal in this article, then, is to demonstrate the by now familiar but nonetheless instructive lesson that objects have "biographies" over the course of which meanings accumulate and shift in ways that engage and inflect larger social forces (Kopytoff 1986; see Alberti 2005; Geary 2006; Gosden and Marshall
1999). That is, the article offers preliminary notes on the social life of the Black Collection. In so doing, it puts the collection in the specific economic and political contexts of its creation, purchase, and display; more precisely, it foregrounds the historical relations of power and agency through which the work of acquisition and exhibition has been performed (e.g., see Clifford 1988; Hinsley 1992; O’Hanlon and Welsch 2000; Phillips and Steiner 1999). It also contributes to understanding the geographical nature of collections and practices of collecting, that is, the ways in which processes of acquisition and exchange stretch across space and trace a network of mutually defining objects, people, and places (Hill 2006). ${ }^{3} \mathrm{My}$ method is thus an instance of the tracking strategies and follow-the-thing approaches that have become an increasingly standard feature of multisited research done by anthropologists and geographers (see Foster 2006).

\section{Biographies AND Networks}

Kopytoff states that a "culturally informed economic biography" would understand a thing or set of things "as a culturally constructed entity, endowed with culturally specific meanings and classified and reclassified into culturally constituted categories" (1986:68). 
The emphasis falls heavily on process, on how the semiotic and economic value of a thing shifts as it moves from one category (such as "curio") to another (such as "art"). This movement, Kopytoff argues, characterizes highly commoditized societies in which individuals and small groups of people continually produce new classifications, or "singularizations," in response to the homogenizing effects of "the only reliable public valuation," namely, market price (Kopytoff 1986:88). In such societies, "an eventful biography of a thing becomes the story of the various singularizations of it, of classifications and reclassifications in an uncertain world of categories whose importance shifts with every minor change in context" (Kopytoff 1986:90).

Kopytoff's approach to the social life of things accords well with the concerns of many scholars who seek to dispel what Shelton (2005) calls the "commodity disavowal" that warps both ethnographic and art historical treatments of objects, especially in museum displays. Instead of understanding things to signify either discrete ethnic groups or universal aesthetic criteria, Shelton (2005:94) urges scholars to refocus "attention on the history of the processes and conditions of the appropriation of objects" (see Thomas 1991). The result of such effort would be to recover the sometimes spatially extensive networks through which things (such as "Trobriand" lime spatulas or "Admiralty Islands" obsidian daggers) circulate. These material and political networks connect a heterogeneous array of people who are motivated by a diverse set of definitions of what matters about the things that pass through their hands. From this perspective, then, things are always hybrid; they refer to multiple, often incompatible, senses of value and significance that agents in the network negotiate and contest (see Phillips 2009).

These considerations prompt the notion of a networked biography, a term that despite its inelegance serves to suggest that a biographical approach to things entails tracing the network of social relations in which things are caught up or entangled at any given moment (Gosden and Marshall 1999; Phillips 2007; Thomas 1991). Put otherwise, people and things, linked together, mutually define each other's value and meaning (see Munn 1983). As these links accumulate, atrophy, and shift over time, the meaning and value of things-like that of peo- ple-also change. Accordingly, writing the history or biography of a thing involves paying attention to changes in the shape of the network that links people and things, that is, to the ways in which things come into and drop out of relation with other things and become attached to and detached from particular persons. The result would be an account that treats both people and things "as moving moments within networks of relations" (Gosden and Marshall 1999:173; see Strathern 1988) rather than as stable and discrete entities that exist in and of themselves.

The notion of a networked biography thus highlights how things in one context of social relations might become things of another sort in a different context: commodities become gifts, curios become art, and vice versa. In this respect, networked biographies complement exercises in critical museology that emphasize how the manner in which a thing is displayed or exhibited conditions the value and meaning of the thing (e.g., Vogel 1988; see Phillips 2007). But a networked biographical approach also has other implications for how we think about museumsinstitutions sometimes regarded as warehouses of inert objects. The museum itself is composed of an incalculably large number of relations between people and things:

If a single object can pass through numerous hands before becoming absorbed into a Museum's collections, then the Museum as a whole encompasses a series of vast, complicated networks of people, many of whom would never have come into contact, or come to value their contact, had it not been for objects. [Gosden et al. 2007:5]

The museum, in short, is a relational and dynamic entity, at any given moment one node in a larger network of relations that shift and change over time. Accordingly, writing the history or biography of a museum involves attending to the multiple interconnections between people and things that have composed the institution, without pretending to be exhaustive or final. This article thus contributes to the relational history not only of the Buffalo Museum of Science but also of the Australian Museum in Sydney, whose agents were consequential actors in the network of relations through which the P. G. T. Black 
Collection was initially assembled and subsequently sold.

\section{Moment 1: Assembling the Collection}

\section{The Traffic in "Native Things"}

In July of 1912, toward the end of a nearly fouryear long collecting expedition, the American anthropologist A. B. Lewis wrote to his Field Museum colleague S. C. Simms:

I have been in British N.G. since the early part of February. It is not as interesting as German N. G., as the country has been longer settled, and also contains many more persons. The white population is estimated at about 1,000, and nearly every man is, or has been on the lookout for "curios." With very few exceptions, these have all been sent away to Australia or England, so there is little to be seen here. [Welsch 1998:450]

Lewis probably would have regarded Black as one of those men on the lookout for curios. Black made four separate trips to British New Guinea/Papua in 1893, 1899, 1902, and 1910, inspecting the account books of BP's branches at Port Moresby and Samarai. His diaries make it clear that during these visits he would also travel, by foot and by boat, through the areas surrounding Papua's only two port towns. Although labeled as "diaries," these slim leatherbound books are properly itineraries, consisting mainly of one-line entries that note Black's movements on select dates. ${ }^{4}$ For example, on his 1893 trip Black walked to the junction of the Laloki and Goldie rivers outside Port Moresby and sailed up the coast to Yule Island and on to Daru before returning to Australia via Thursday Island. On his 1899 trip, he sailed from Samarai to nearby Normanby, Dobu, Fergusson, and Goodenough islands; on his 1902 trip, Black visited Woodlark Island (Muyuw), which at that time was the site of a gold rush (see Nelson 1976). Adventurer and travel writer Beatrice Grimshaw (1911) provides a richer account of excursions along some of these early established routes for visitors in her unwholesomely vivid impressions of the Territory of Papua, The New New Guinea.

Black's papers are frustratingly silent on his collecting activities; they offer no description of encoun- ters through which he might have acquired things. It is nonetheless reasonable to assume that he acquired some of the objects in his collection during side trips from Port Moresby and Samarai. A provocative piece of evidence for this claim comes from one of Black's diary entries during his 1902 trip to British New Guinea. On November 22, Black left Samarai on the lugger "Hecla." His entry for the next day reads: “Through Suau passage@10am. Landed@Suau and Naguna (Mutuaga's place) left 1pm." Mutuaga was a reputable and innovative carver whose distinctive naturalistic style has been meticulously analyzed by Harry Beran (1996). Several of Mutuaga's carvings are now in the Black Collection, two of which appear in the catalogue for the 1946 show at MoMA (see Linton and Winegart 1946). The carvings include large lime spatulas, a walking staff, and a freestanding sculpture set on a three-legged base that strongly suggests how Mutuaga was carving curios tailored to European tastes and preferences (Figure 5). ${ }^{5}$

Black may have heard of Mutuaga from Charles Abel. Black's diaries record two visits in 1899 to Abel's London Missionary Society station on Kwato Island near Samarai (see Wetherell 1996). Abel was a patron and promoter of Mutuaga's work (Beran 1996), and Black could have acquired items for his

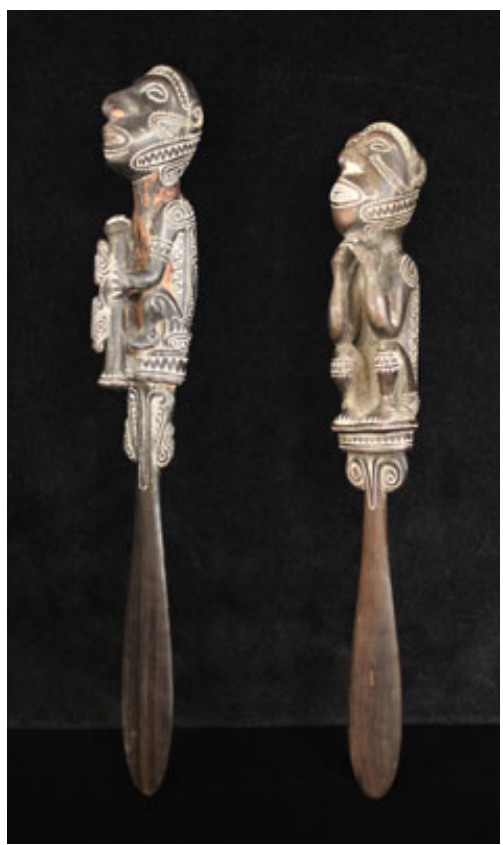

Figure 5. Lime spatulas, carved by Mutuaga of Suau area (Milne Bay Province), Papua New Guinea. (Courtesy Buffalo Museum of Science, C8335 and (8337.) 
collection directly from him and, like A. B. Lewis after him, from other resident missionaries (e.g., on Yule Island, where Black stopped in 1893). Missionaries like Abel were stimulating the production of indigenous crafts elsewhere in the region. By the 1920s, local craft items from the Solomons were being marketed by the Melanesian Mission in Australia and New Zealand (see Stanley 1989). Comparison of Black's own typed catalogues indicates that several pieces attributed to Mutuaga were added to the collection after 1901, perhaps acquired personally from Mutuaga during Black's three-hour visit to the carver's village. The 1914 catalogue adds a note to the description of items that were listed in the 1901 catalogue as "Suau (South Cape B. N. G.) Carvings": "All carved in ebony, Carved by 'Mutuaga', celebrated in New Guinea for the excellency [sic] of his work."

How else did Black acquire things other than personally? And what might such acquisitions tell us about the relations of power and agency performed in making Black's collection? The questions are pertinent inasmuch as a comparison of objects in the collection with Black's travel itineraries reveals that many items came from areas that Black apparently did not visit himself, including the area around Tufi in present-day Oro Province (Papua New Guinea) and, surprisingly, the Trobriand Islands - a busy site of European activity in the 1890s as a result of the presence of both Methodist missionaries and commercial pearl traders. Black's collection thus indicates the operation of a vigorous intercultural economy that involved sundry foreign agents and indigenous people in exchanges for each other's stuff. By 1912, this activity had already resulted in what struck A. B. Lewis as a condition of outrageous inflation. Lewis unhappily reported to Simms: "Native things are high now; stone clubs bring from $\$ 5$ to $\$ 20$ or more. I have known $\$ 15.00$ paid for a medium sized stone ax blade, chipped at that" (Welsch 1998:450).

One of Black's agents in these exchanges was the intrepid A. S. Meek, who collected specimens of birds and butterflies for Lionel Walter Rothschild's impressive private museum in Tring, Hertfordshire, England. Meek's 1913 memoir, A Naturalist in Cannibal Land, offers occasional glimpses of how trade for goods and services operated in Melanesia circa 1900. Meek reports that he mainly used tobacco and iron or steel (knives and tomahawks) as trade currency, although he found that salt supplemented with beads was more effective when collecting in interior New Guinea. Rates of exchange varied from place to place. So, for example, Meek noted that he was once able to purchase three skulls from some "New Guinea natives" with a single stick of tobacco, whereas "in the Solomon Islands the natives set a very great value on their human skulls, and will hardly part from them at any price" (1913:53). Similarly, Meek evaluated the labor he secured from local (indigenous) workers in monetary terms with reference to a ranking of trade goods. While salt and beads might amount to "small change" for buying local produce, knives and tomahawks were "big money": "You would only pay out big money for carrying work or collecting work. Perhaps a knife would be paid as the wages for a journey, or a looking-glass, or perhaps both" (Meek 1913:154).

Meek's comments on the comparative value of human skulls call attention to the international networks that had come into existence by the late 19th century to facilitate the removal of indigenous human remains from the colonial world to metropolitan Europe (see Fforde 2004:57-59). Post-Darwinian physical anthropology was slow to abandon polygenism in accounting for human diversity and perforce justifying European imperialism and, subsequently, American racism (Stocking 1968:42-68). Accordingly, human remains - above all, skullsoften entered the collections of universities, scientific societies, and institutional museums as "specimens" thought to provide evidence for the classification of distinct and hierarchical races. But human remains also found their way into the hands of auction houses and individual dealers who offered them for sale in catalogues along with other "curiosities." For example, Torrence and Clarke (2011) note the high prices commanded by skulls as well as weaponry (stone clubs and axes)-items advertised as suitable for the decoration of billiard and smoking rooms and other masculine spaces in Victorian and Edwardian homes.

Meek's exchanges were not always mutually satisfactory. He recalls, for example, how he persuaded villagers along the Giriwu (or Girua) River (in present day Oro Province, Papua New Guinea) to part with an ancient stone carving with red markings that "had 
been installed in a place of honour in the village, and was associated by the natives in some way with ideas of fruitfulness" (Meek 1913:177):

On that trip to the Giriwa [sic] River I secured from the natives a small stone image which was evidently a relic of a prehistoric race. I had noticed this image in one of the villages and was anxious to obtain it to send to Europe as a curio. The natives were reluctant to part with it, but finally yielded to the temptation of an offer of two axes, but after the bargain had been struck and when one of my boys was carrying away the image, the natives seemed to be seized with some regret. To leave them thoroughly satisfied I was obliged to give them some red turkey cloth in addition to the two axes. [Meek 1913:176]

The stone carving was one of several prehistoric stone artifacts (such as a $66 \mathrm{lb}$ mortar and accompanying pestle) that were found and removed by European prospectors working in the Yodda Valley goldfields in the years around Meek's visit (Figure 6; see Etheridge 1908; Lyons 1950). The 1907 annual report for the Territory of Papua mentions Meek's "curious find" and describes it as anthropomorphic, "in the shape of the upper portion of a man's body, cut out in hard stone, and 20 inches in height." The report notes further that "it is a great pity that it was allowed to leave the country. I understand that it was

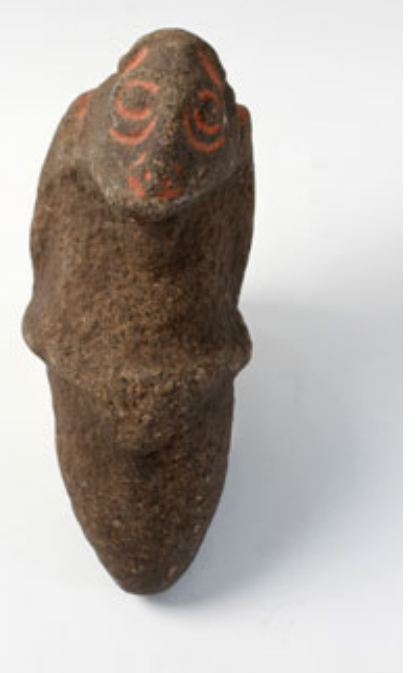

Figure 6. Stone animal figure, Girua River headwaters (Oro Province), Papua New Guinea. (Courtesy Australian Museum, E.65324. Photograph by 0. Perkins 2012.) sent to P. G. Black, Esq., of Messrs. Burns, Philp, and Co., Sydney" (Commonwealth of Australia 1908:56).

A 1950 article in Pacific Islands Monthly by A. P. Lyons exposes Meek's mistake about the satisfaction of the villagers with the offer of two axes and some red turkey cloth. Lyons, assistant resident magistrate at Buna Bay government station in 1907, writes that he saw the relic and spoke with Meek, who departed by vessel on the same day that he arrived from the Giriwu River. Lyons continues:

The following day some Giriwu natives came to Buna, and complained to me that a native had secretly disposed of the relic to Meek for "trade goods." They did not know where the relic originated, or how or when it came into possession of their tribe. It was quite clear to me that they regarded the relic with awe.... A few weeks later, the Giriwu natives complained to Judge Murray (afterwards Sir Hubert Murray) about the matter, when he passed through their country on his way to Kokoda. [Lyons 1950:59]

The trade in curios, although shaped in part by the agency of local people, as I will demonstrate, was hardly always a fair deal. Meek privately confirmed as much in a communication to Black (even if Meek might have been inflating the value of the carving for Black):

The natives evidently thought a good deal of it, for they would not let me touch or handle it until I produced very considerable quantities of tempting trade in exchange. Even then they repented, and wished to return the trade. It evidently belonged to the village and to no one man in particular, and was rather regarded as a Mascotte judging by the way they had it painted up. ${ }^{6}$

The value of Black's acquisition was not lost on Robert Etheridge, Jr., a paleontologist and curator of the Australian Museum in Sydney. Black and Etheridge corresponded frequently about artifacts and natural history specimens that came into Black's possession, some of which Black donated to or exchanged with the Australian Museum. Black lent the Giriwu stone carving to Etheridge so that a cast could be made for the museum, and Etheridge described the carving in a publication on stone imple- 
ments from the Yodda Valley: "The object represents a rude animal figure, fourteen and a half inches long by six inches wide, and weighs 17 lbs.” (1908:26). (In that article, Etheridge acknowledges "the well known Sydney collector Mr. P. G. Black.”) Black subsequently replied to Etheridge's request for more information about the provenance of the object, conveying information that Black had received in letters from the "friend" (i.e., Meek) who supplied him with the specimen. In response to Etheridge's query about the red markings on the stone, Black reported:

As regards the colour, this has been recently affixed. My friend states that he took the carving down to the Creek and scrubbed the paint off (i. e. the red paint which he found on it at the point of acquisition). However, finding that the paint accentuated the markings, he re-placed the same. $^{7}$

C. A. W. Monckton, a former resident magistrate in British New Guinea and author of several accounts of his experiences, notes in Last Days in New Guinea that:

My friend, Mr. P. Black, of the firm of Burns, Philp and Co., Sydney, has, I understand, a very good collection of peculiar and interesting objects dug up by the miners in New Guinea, and purchased for him by their firm's manager. This collection should be examined by a scientist. [Monckton 1922:118] ${ }^{8}$

The Black Collection includes numerous stone axe heads and adze blades but not the Giriwu carving, which is now in the Australian Museum. The carving was not, however, donated by P. G. Black; it was held apart from the collection of artifacts that went to Buffalo, as Wulric Black informed Pacific Islands Monthly in a response to the article by Lyons (Famous Black Collection of Artifacts 1950). Perhaps it was kept on display at the Black family residence, "Tatlow," in Neutral Bay on the north shore of Sydney Harbor (and later at Wulric's home). Did P. G. Black retain it as a token of his friendship with Meek? Was Meek, who traveled extensively in Papua and the Solomon Islands, one of the principal means by which Black acquired things? When Chauncey Hamlin wrote to Black's son Wulric for more information about how P. G. Black assembled the collection, Wulric attempted to contact Meek as a person who, in particular, "knew a good deal about his [P. G. Black's] collection." In addition, Meek's Queensland mailing address appears in the address book that P. G. Black owned at the time of his death in 1921. In any event, Wulric Black donated the Giriwu stone carving along with five other Melanesian artifacts to the Australian Museum in 1972. Then Assistant Curator of Anthropology James Specht described it as "one of the most important accessions into our collection this year."10 The carving was displayed in the Australian Museum's exhibit Pieces of Paradise in 1988 (Australian Museum Trust 1988). ${ }^{11}$

Despite its inequities, the traffic in "native things" also reflected the agency and intentions of indigenous islanders. This agency involved more than simply refusing to part with items such as skulls or ceremonial masks or canoe ornaments (see Grimshaw 1911:146, 303). For example, Meek metaphorically observed of his wage payment practices in New Guinea that: "The biggest money-the native Bank of England $\mathfrak{E} 5$ note, so to speak-is pearl shell, which the inland natives value very highly" (1913:154). Foreign traders like Meek therefore often turned themselves into suppliers of indigenous goods for indigenous consumption. A. B. Lewis quoted the prices that indigenous people would be willing to pay for local goods: "Shell arm bands the natives themselves will buy at $\$ 20$ to $\$ 50$ apiece. Shell money is worth up to $\$ 5.00$ a foot. Feather ornaments are also very valuable" (Welsch 1998:450). European traders would insert themselves as brokers in this economy of compelling indigenous desires. Thus Meek explains how traders would visit Woodlark Island in search of the greenstone axe blades ("tomahawk stones") valued throughout the east end of New Guinea: "Traders bring to Woodlark Island to barter for tomahawk stones the shells which are very general currency throughout the island and which are worn as armlets" (1913:73). In this way, European traders articulated the demand of Woodlark Islanders for shell armlets with the demand, say, of Trobriand Islanders for greenstone blades. ${ }^{12}$

Charles Arbouin, BP's branch manager at Samarai from 1895 to 1902, was one of several Europeans who commissioned the manufacture of shell valuables for use as "native money" or "Papuan trade." These valuables were made to entice islanders to labor as 
pearl divers in the Trobriands and to purchase copra and gold dust from islanders in the Louisiade Archipelago (see Lepowsky 2001; Nelson 1976). It is possible though not yet documented that Arbouin purchased "peculiar and interesting objects" on behalf of Black, as Monckton's comment suggests. A similar arrangement, however, has been documented: the pearl trader Billy Hancock helped Malinowski assemble a collection of "Trobriand ethnological artefacts" for the National Museum of Victoria in Melbourne (see Young 2000).

The result of all this intercultural commerce could take the form of odd translations across wildly different registers of value. Consider, for example, the following transaction. While collecting on Santa Isabel in the Solomon Islands, Meek heard of an unrecorded species of large chestnut colored owl, a specimen of which he sought. In order to secure his goal, Meek provided a local worker with a shotgun and cartridges, promising a reward of ten arm-rings for a specimen of the owl (Pseudoptynyx solomonensis). Meek (1913:104) reckoned that each arm-ring was worth approximately two shillings, thereby establishing monetary equivalence and material connection between the worker's desire for shell rings and Baron Rothschild's desire for new bird specimens. ${ }^{13}$

European traders sold shell valuables in Samarai not only as "Papuan trade" to other white traders but also as curios to visiting Europeans, including the tourists who traveled to BNG/Papua on BP's ships. Elizabeth Mahony sold the shell necklaces that she commissioned islanders to produce on her coconut plantation in Sudest (Vanatinai) to white visitors to the Cosmopolitan Hotel, which she ran in Samarai (Lepowsky 2001; see Grimshaw 1911:301). Charles Arbouin was an employee of Mahony and her husband in Sudest and Samarai before working for BP and by 1914 was listed in Stewart's Handbook of the Pacific Islands as a trader on Rossel Island, source of the red shells used to make sapisapi (soulava in Kiriwina), the necklaces that circulate in kula exchanges. During her visit in 1908, Grimshaw noted, "The trader resident on Rossel [perhaps Arbouin?] has instituted a mint on a small scale, where he employs the natives making [shell] money for him, when he has no other work for his indentured boys" (1911:294).
The curio trade in southeastern Papua also linked up with the trans-Pacific traffic of gold prospectors and sailors. Things such as war clubs, greenstone axe blades, and lime spatulas found their way to goldfield gateways in California and the Northwest United States. Some turned up for sale again in stores such as the Old Curiosity Shop on Geary Street in San Francisco. At a transformative moment in its biography, the inventory of the Old Curiosity Shop-which contained hundreds of items from the Trobriands and neighboring islandswas purchased in 1901 by Phoebe Hearst and donated to the anthropology museum at the University of California, Berkeley, which now bears her name (see Lepowsky 2001; cf. Duncan 2000). Curios became ethnological specimens.

\section{Curios or Specimens? P. G. Black as Scientific Collector}

Although his collecting undeniably took place in the context of a vibrant trade in "native curios," it is less certain that Black imagined his own activity in these narrow terms. A curio, after all, is an item of singular interest; it provokes excitement without much regard to its particular place in any larger scheme of things. A scientific specimen, by contrast, implies a classification in terms of which things take on meaning and value. Black's relationship with Etheridge suggests that Black maintained a scientific interest in the objects that he collected. Indeed, Black was well positioned to convert the "curios" that he acquired from people like Meek into "ethnological specimens" suitable for acquisition by the Australian Museum.

There is further evidence of Black's broad scientific interests. He collected, for example, not only ethnographic objects but also shells - at least some of which were displayed in the drawing room of "Tatlow" (Sun 1926). He was elected a member of the Linnaean Society of New South Wales, in the proceedings of which for 1900 Charles Hedley, a naturalist and conchologist at the Australian Museum, refers to the conch collection of his "friend, P. G. Black." The proceedings of the Malacological Society of London for 1904 record a description of a new species of shell, Planispira (Trachiopsis) blackiana, that H. B. Preston named for Black, from whom he had received several specimens (Preston 1905:207). Black's correspondence with Etheridge reveals many 
donations of natural history specimens as well as several requests for identifications. His 1914 catalogue of ethnographic objects also lists 40 bird skins (including a few bird of paradise species). Black also made trades with the Australian Museum in which he requested natural history specimens in exchange for ethnographic objects.

Black's collecting went beyond natural history. He also collected postage stamps, which he evidently did not buy or sell but acquired only through his far-flung network of Burns, Philp employees or, on occasion, by giving exact face value for stamps sent to him at his request (Smyth 1921). In a similar vein, although Black made exchanges, he never sold items to the Australian Museum (perhaps thereby following the same management principles that guided his stamp collecting). Collecting, moreover, seemed to be an integral part of the family's life. Black's wife Irene was a collector of miniature objects, including toy tea sets, as well as dolls, which were displayed in large glass cabinets at Tatlow (Woman's Budget 1931). Black's daughter, Australia, collected not only miniatures, but also spoons from different countries (Sun 1926). The Buffalo Museum of Science now holds, along with Black's various papers, several autographed fans that appear to have been part of Irene Black's collection.

Unlike other affluent men of his day, Black apparently did not exhibit his large collection at home, although one newspaper account of his wife's collections refers to an "island love token" on display - a necklace fashioned from thousands of beetle legs (Sun 1926). Instead, with the exception of a few items such as the Giriwu carving, Black stored his huge collection of Oceanic things in wooden cases in the basement of BP's headquarters in Sydney. It is worth noting that Black's collection does not feature imposing or singularly exotic objects; it emphasizes the mundane as well as the small. ${ }^{14}$ There are plenty of weapons and many feathered items of ceremonial ornamentation, to be sure, but the collection also includes a large number of household utensils, pieces of fishing gear, items of everyday dress, paraphernalia for betel nut chewing, and so forth. The collection, moreover, contains multiple copies of many objects; for example, there are two dozen "pineapple"-style stone clubs and more than two hundred lime spatulas listed in the collection's inventory as coming from the Trobriand Islands alone. Many of these spatulas show signs of use and wear; they are not objects produced expressly for trade, as was the case with some of Mutuaga's spatulas and carvings. Similarly, there are some examples of unfinished objects (such as shell arm rings) at different stages of manufacture.

These facts invite speculation. First, Black's collection reflects a scientific approach to acquisition in the mode of natural history. Multiple copies of an object define a range of variation, and examples of unfinished objects illustrate the process of transformation through which an object passes. Black's acquaintance with the naturalists Meek and Hedley, his membership in the Linnaean Society, and his interest in collecting shells, bird skins, and other natural history specimens all support this claim.

More specifically, Black's collection seems to reflect the application of zoological principles to ethnographic materials. His 1901 catalogue suggests that much of the collection was stored in cases organized according to object type-"Bows and Arrows," "Spears," "New Guinea Stone Clubs (On Handles)"-although some categories of objects were also grouped by locality: "Trobriand Island Wood Clubs," "Solomon Island Clubs," "New Hebrides Clubs."

The zoological approach to material culture is associated with the biologist-turned-anthropologist A. C. Haddon. Anita Herle notes that Haddon studied decorative art as a branch of biology, plotting

the geographic distribution of object types and decorative designs within specific regions. As a large number of samples was crucial for analysis, he closely compared the details and variations of hundreds of objects, using examples from the field as well as numerous objects in museum collections throughout Europe.

[1998:82]

Black's emphasis on normal and average material rather than "extraordinarily dazzling items" recalls the collecting advice of Adolf Bastian (Young 2000:184). This emphasis also fit well with Haddon's vision of the museum as a storehouse of "complete 'sets' of material culture; huge collections were seen as essential data banks for further anthropological research" (Herle 1998:96-97). Was Black using Haddon's publications as a field guide to collecting, perhaps in the way that missionary collectors of the 
Melanesian Mission in the Solomon Islands are thought to have used R. H. Codrington's book, The Melanesians (Stanley 1989)?

Black's diaries indicate that he was at Thursday Island in the Torres Strait in April of 1898. Was it possible that he met Haddon and other members of the famous Cambridge anthropological expedition who arrived that month? There is one piece of indirect evidence that Black at least knew of Haddon's work: an unelaborated reference in Black's memoranda to Haddon's 1898 publication, The Study of Man. More significantly, there is a documented connection between Haddon's and Black's collecting activities. In 1908, Black donated 49 Torres Strait artifacts to the Australian Museum (Florek 2005). He acquired the artifacts from John or "Jack" Bruce, the resident school teacher stationed on Mer (Murray Island) since 1892, perhaps during one of Black's frequent inspection trips to Thursday Island. In 1905, Bruce had sent Haddon a set of artifacts "similar in composition and number" to the set acquired by Black (Florek 2005:42). Both sets appear, at least in part, to have been commissioned by Bruce; each set contains a mourning costume worn by a widow or widower during the mourning period. Haddon had witnessed a funeral in 1898 in which he noted that such mourning dress, due to the adoption of Christianity and the missionary influence, was no longer used. It would appear, then, that "both sets were collected at the same time prior to 1905, and presumably the second set that was not sent to Haddon was eventually obtained by Black" (Florek 2005:43). ${ }^{15}$

Black might have been assembling his collection with an eye toward the ethnological concerns of his day. He corresponded with C. G. Seligman, arranging transport for the 1903 Cooke Daniels Expedition that Seligman led to New Guinea (Seligman 1904, 1905) and subsequently supplying Seligman with photos of spears that Black had himself collected in Merauke (Seligman 1906). His diaries reveal an interest in contemporary anthropology: the entry for July 30, 1914, indicates that he attended an evening lecture at University Hall in Sydney given by Professor Grafton Eliot Smith on the influence of Egypt on the development of Western civilization. Smith was one of the delegates to the meetings of the British Association for the Advancement of Science held in Australia during the month of July 1914. Among the other notable
British anthropologists attending the meetings were three veterans of the Torres Strait expedition: W. H. Rivers, C. G. Seligman, and A. C. Haddon.

There is perhaps a complementary or even alternative explanation for the character of the Black Collection. We might regard Black as a deliberate countercollector of the material culture that was being transformed if not wholly displaced by the trade-store consumer goods - metal fish hooks and cooking pots, cotton cloth, and so forth - carried on Burns, Philp's ships and sold out of Burns, Philp's depots in Port Moresby and Samarai. Or maybe that was precisely the material culture that indigenous Melanesians were happy to let go.

Nevertheless, I do not dismiss the possibility that Black was acquiring things with the intention of either trading them for scientific specimens or selling them as native curios. Perhaps the multiple copies in the collection would thus be offered for natural history specimens, such as the beetles and minerals that Black acquired in exchanges with the Australian Museum. Black's address book contains an entry for W. D. Webster, a prominent English dealer who issued some of the first illustrated catalogues offering "ethnographical specimens" for sale (see King 2006; Torrence and Clarke 2011). Perhaps Black used Webster's catalogues rather than Haddon's treatise as a guide for his collecting. Or perhaps Black was planning to follow Webster's example of dealership and use the collection as a resource for funding his eventual retirement from Burns, Philp.

\section{Moment 2: Claiming Australian national PATRIMONY}

At the time of his sudden death in September 1921 at the age of $60, P$. G. Black had risen to the positions of general manager and director of Burns, Philp. Black's obituary in the Sydney Morning Herald mentions his valuable "collection of curios" for which offers of purchase from American and other museums were allegedly consistently refused. In his lifetime, Black did donate fossils, mollusks, bird skins, and shells as well as artifacts to the Australian Museum. He seems, however, to have left no instructions for posthumously donating the collection to the Australian Museum or to any other institution. There is scant evidence to suggest that Black was collecting out of a sense of patriotism or civic duty. 


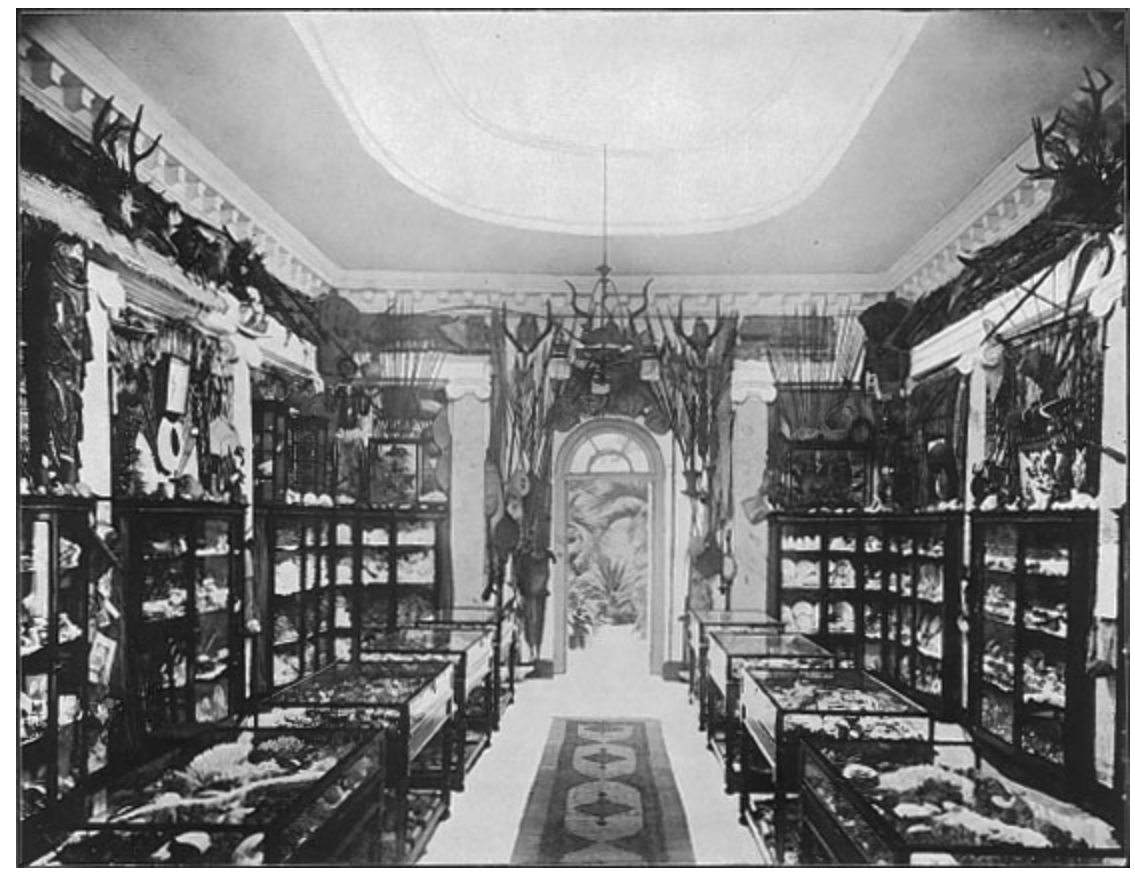

Figure 7. The museum at Gowan Brae, estate of Sir James Burns, 1922. (Courtesy Buffalo Museum of Science.)

In addition, there is no evidence to suggest that Black was collecting with the aim of accruing personal honors for himself, in the manner of many colonial officials in German colonies - such as Franz Bulominski in New Ireland (German New Guinea)—who competed for medals and titles with their donations to ethnographic museums (see Rosman and Rubel 1998). He did not indulge in conspicuous consumption. It is possible, however, that some of the objects that Black collected were displayed at the home of his employer, Sir James Burns, whose estate (known as Gowan Brae) on the outskirts of Sydney north of Paramatta contained a museum (Figure 7). ${ }^{16}$

In September of 1922, Black's son Wulric (P. T. W. Black) wrote to the Australian Museum, communicating the wish of the trustees of his late father's estate that the collection "should, if possible, be disposed of in such a manner as would assure its preservation for all time." ${ }^{17}$ The asking price was $\mathfrak{E} 3,000$. Charles Anderson, a mineralogist who after Etheridge's death in office became museum director in February 1921, responded that his institution lacked the resources to buy the collection, but it would establish a committee "for the purpose of arousing public interest, stressing the desirability of the collection being secured for the Museum, and endeavouring to raise funds for its purchase." 18
For the next year, the Sydney Morning Herald regularly ran articles that represented Black's collection as a piece of national patrimony at great risk of being lost. Black's collection had become the Black Collection; collective possession eclipsed Black's individual ownership. On December 8, 1922, the newspaper printed an essay by Professor Sir T. V. Edgeworth David, the Welsh-born Australian geologist and Antarctic explorer, who described Black's assemblage as "the finest ethnographic collection from the South Seas ever made by one man." He noted that it was no longer possible to secure such specimens due to their displacement by "the white man's 'trade," and he highlighted the provenances and contents of this "most extensive and valuable collection." David concluded with an appeal:

This fine collection has been offered to the Australian Museum for a sum of $£ 3,000$ and the trustees of that institution are desirous of acquiring it, but unfortunately they have not the necessary funds. Here is a golden opportunity for some wealthy Australian with sufficient patriotism and public spirit to provide the purchase money so that this unique collection may not be lost to Australia, but may be retained in some national institution such as the Australian Museum for the benefit and instruction of the present and future generations. [Sydney Morning Herald 1922:8] 
Several months later, on July 4, 1923, an unsigned item in the newspaper warned that the Black Collection "is likely to go to America, unless sufficient money is raised to keep it in Australia." The item reported the initiative of residents of towns in the northern part of New South Wales to raise the purchase price by either influencing a wealthy resident or undertaking a public subscription. This notice was followed the next day by an editorial that accused Australians of "culpable indifference" in preserving not only their natural heritage but also their cultural heritage: "Things of great historical, scientific, or sentimental importance, which Australia should have cherished, have been allowed to pass into the possession of others" (Sydney Morning Herald 1923:8). The Black Collection was adduced as merely the latest example of an important part of Australian national patrimony facing dispersal overseas. The unsigned item and editorial were likely the work of the committee established by the Australian Museum and chaired by David for the purpose of raising funds to buy the Black Collection.

The July 1923 editorial is notable for how it recruits the Black Collection into a particular definition of the Australian nation. On the one hand, it concedes that the collection "concerns Australia less directly" than other collections that had already gone abroad. On the other, it emphasizes Papua's political connection to Australia: "Papua has been the chief contributor to [the collection], and the fact that Papua is an Australian Territory is in itself an argument for the retention" (Sydney Morning Herald 1923:8). (It is worth noting that no mention is made in this regard of the Australian Aboriginal materials in Black's collection.) Papua's political status as part of Australia is at this moment invoked explicitly; a future for Papua, other than one of eventual political independence, is certainly kept open if not taken for granted. This usage is in sharp contrast to the official government policy of postwar Australia to disguise Papua's actual political status behind Australia's role as administrator of a UN Trust Territory. In support of an Australia that includes Papua, the editorial appeals for a demonstration of "public-spirited liberality" in raising the purchase price. Failure in this enterprise would only ensure that once again American museums and collectors would deprive Australia of material "with which we should never have parted" (Sydney Morning Herald 1923:8).

The rhetoric of deficient civic pride, government parsimony, and lack of public spirit continued in newspaper articles in the Sydney Morning Herald and Daily Mail until the end of 1923. But in the end, there was no competition among Australian towns comparable to the municipal rivalries that enlarged the museum collections of German cities in the first decades of the 20th century (see Penny 1998). Nor did the Australian federal government-perhaps the main target of David's committee's propaganda campaign - step forward with funds to purchase the collection for a planned national museum. It thus remains unclear if the spate of articles in the Australian newspapers can easily be read as an expression of popular nationalism - of the sort of expectation, now so natural, that all legitimate nations require and assume the objective form of a national museum collection (see Anderson 1991). These articles with their threatening references to American buyers banging at the doors might just as plausibly have been attempts by a small number of interested, well-connected individuals (such as Sir Edgeworth David or friends of the late P. G. Black) to apply pressure to local museums and government officials.

In any case, the collection did not go abroad in 1923 or soon thereafter. In November of 1933, twelve years after Black's death, the Sydney Morning Herald reprised its unanswered appeals of ten years before:

An organized movement is now being set on foot to keep this valuable, unique and irreplaceable collection in Australia, whether in one museum, or distributed among several museums. An opportunity is thus provided for patriotic Australians to retain the Black collection in its proper home, which is undoubtedly Australia, and, should be, preferably, Sydney. The loss and the mistake of allowing these famous curios to go overseas would be deplored, not only by the interested authorities, but by Island residents, and other people to whom the collection is well known, some of whom personally may have helped Mr. Black in his lifetime of specimen gathering. [Becke 1933] 
This appeal - which drew no distinction between "specimens" and "curios"-coincided with a joint effort on the part of R. W. Robson and the Pacific Islands Association, F. D. McCarthy and the Anthropological Society of New South Wales, and Sir Colin Mackenzie of the Australian Institute for Anatomy to persuade the federal government to acquire the Black Collection for the national museum still being planned for construction in Canberra. The effort failed when the prime minister's department finally and officially declined the opportunity to purchase the collection on the grounds that sufficient materials, including Sir Hubert Murray's Official Papua Collection (see Schaffarcyzk 2006), were already available for the proposed national museum. ${ }^{19}$

After another four years, an application to export the collection to Buffalo was submitted to the Customs Department of New South Wales. The sale of the Black Collection was finally, and ironically, brokered by an Australian Museum curator (herpetologist James Roy Kinghorn) who, while in Buffalo on a Carnegie Corporation visiting fellowship, told the Buffalo Museum of Science's president Chauncey Hamlin about the cases of artifacts (by then stored in a BP shed on the Sydney wharves). Hamlin purchased the collection sight unseen, planning to display some of it in Buffalo and to use the rest as material for exchanges with European museums. ${ }^{20}$

An undated memo in the files of the Department of Anthropology of the Australian Museum strenuously objects to the application, complaining of the lack of consultation with museum authorities about the trade in and export of ethnological specimens overseas. The author was probably F. D. McCarthy, who in addition to being secretary of the Anthropological Society of NSW, was also curator of Anthropology at the Australian Museum and an early outspoken advocate for the creation of national cultural property legislation in Australia (see McCarthy 1938). The memo states that the Customs Department's "surveillance of all goods sent out of the country is essential if we are to preserve for posterity an adequate record of the cultures of our native peoples." This protest, with its assertion of rights to national cultural property, was not enough to block the issue of an export license. The Black Collection left Sydney bound for New York on February 23, 1938, aboard the ship Yomachichi.

\section{Conclusion: From Patrimony to Art to Curio, Again}

Chauncey Hamlin purchased the Black Collection for the express purpose of including a South Seas alcove as part of a proposed Hall of Primitive Art (see Foster 2012). This hall would complement already existing exhibitions in the Hall of Primitive Races and the Hall of Civilization. As the names of the halls imply, the Hall of Primitive Art would be integrated into an overall museum design that was comprehensively evolutionist, a grand narrative of the development of both the natural and social worlds (see Niquette and Buxton 2009). ${ }^{21}$

Hamlin regarded the Hall of Primitive Art, which opened in 1940, as "a 'first' in the museum world" (1938:7). He believed that "a study of world art 'could evidence the relationship of races' and that by analysis of art motifs 'possible cultural contacts could be explored'" (Gramly 1988:38). Hamlin's project initiated a new moment in the biography of the Black Collection and participated in a larger shift in the value

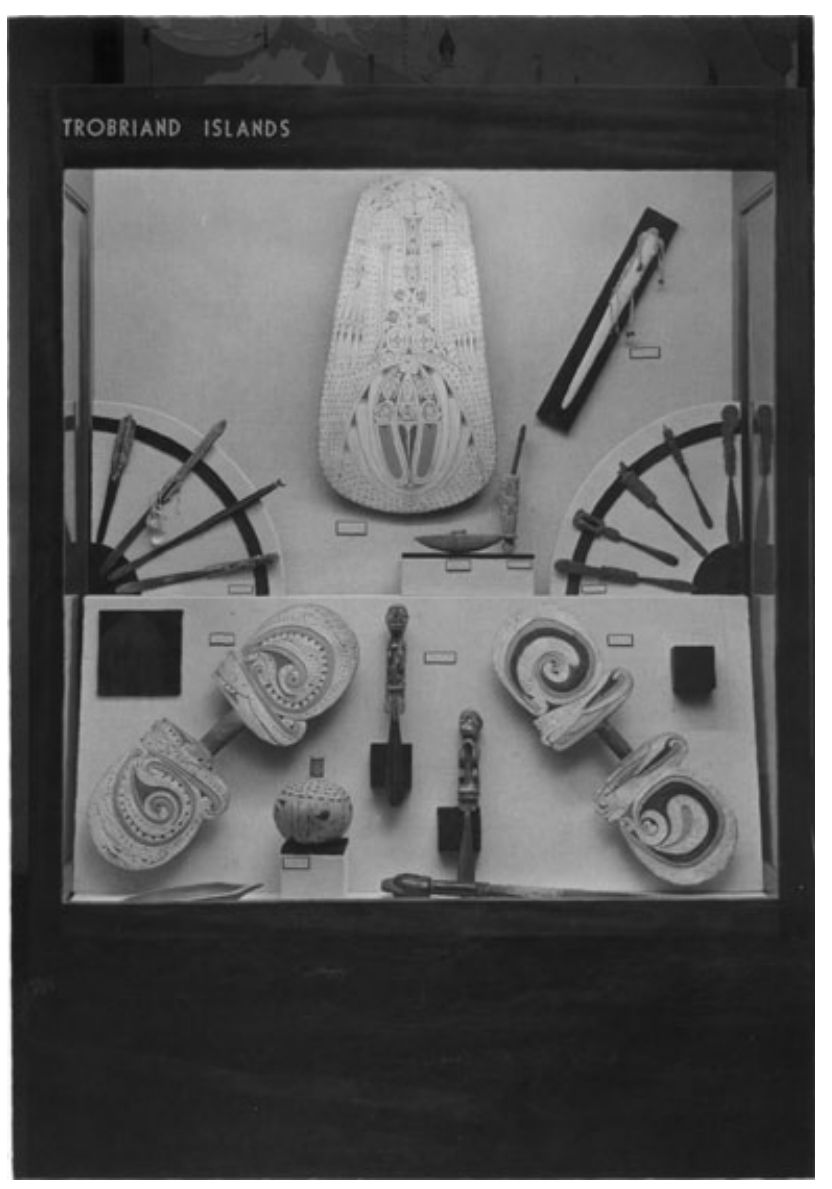

Figure 8. Trobriand Islands display case, Hall of Primitive Art, Buffalo Museum of Science, Buffalo, New York. (Courtesy Buffalo Museum of Science.) 


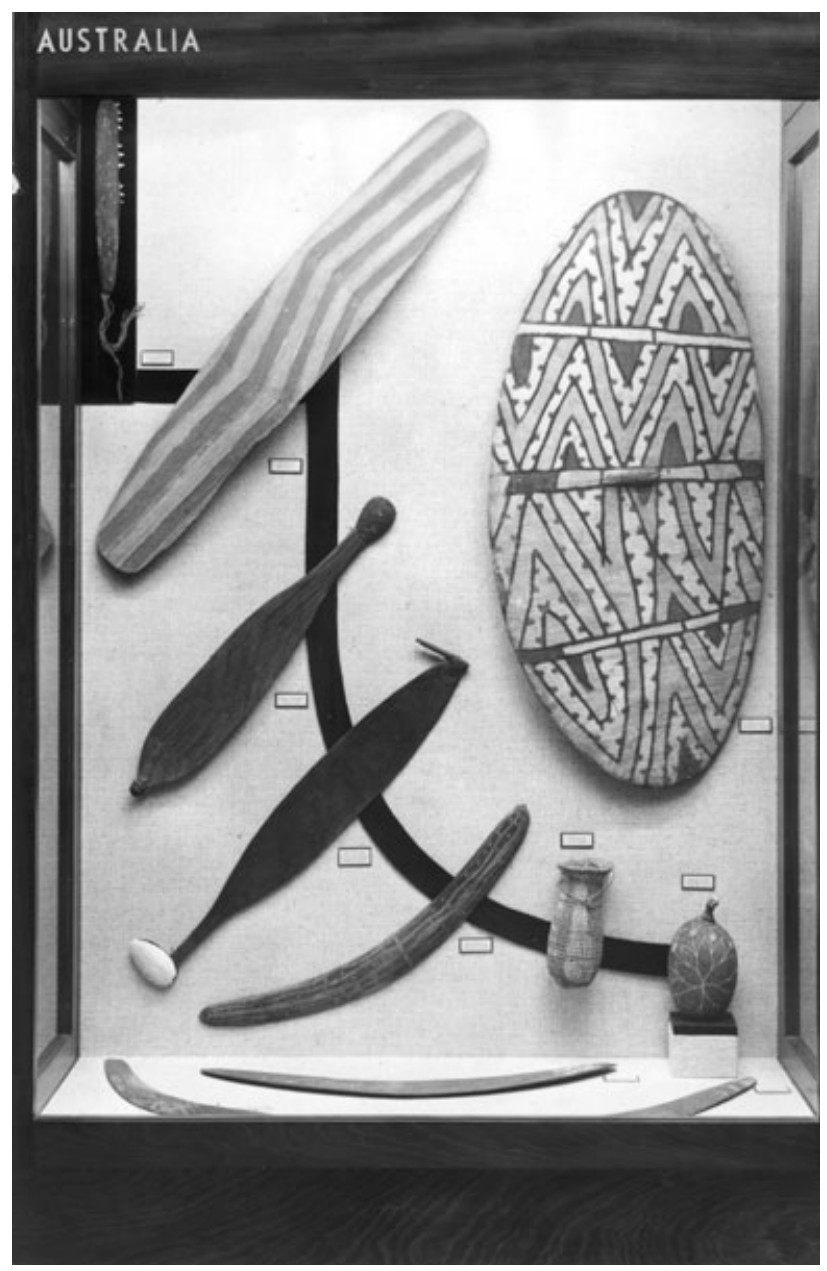

Figure 9. Australia display case, Hall of Primitive Art, Buffalo Museum of Science, Buffalo, New York. (Courtesy Buffalo Museum of Science.)

—economic as well as cultural—of Oceanic things. The transformation of curios and specimens into art defined by universal (formal) aesthetic criteria was well underway. In 1942, for example, the Brooklyn Museum launched Oceanic Art, The Cultures of the Pacific Front, a show that included things from across the Pacific Islands (as well as Indonesia and the Philippines). ${ }^{22}$ The currency of Oceanic art as a cultural category was widely accepted when René d'Harnoncourt launched Arts of the South Seas in 1946, his first major show since being appointed to the Museum of Modern Art, which he would direct from 1949 to 1967. D'Harnoncourt borrowed things from the Black Collection for display in his critically acclaimed installation (see Figures 1, 2, and 5; Foster 2012).

The display cases in the Buffalo Museum's Hall of Primitive Art likewise bore the impress of an abiding concern with aesthetics. (D'Harnoncourt is listed as one of many people with whom the BMS consulted in

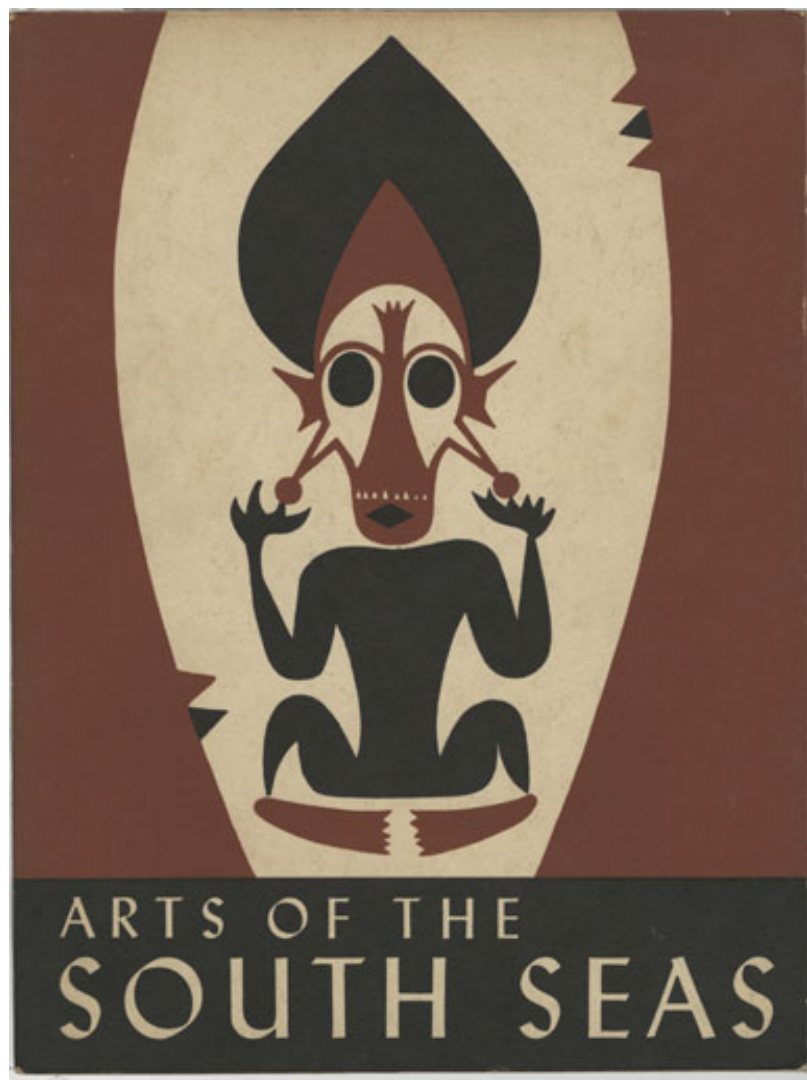

Figure 10. Cover, Arts of the South Seas. (Digital image $\subset$ The Museum of Modern Art/Licensed by SCALA/Art Resource, New York. NB: This image is not available on the HTML version of the article.)

preparing the Hall [see Clawson 1941:xv].) Trevor Thomas, a creative curator who helped install the exhibits, said of the African cases, "As far as possible the materials within the cases are disposed in formal rhythms to emphasize their inherent qualities" (Thomas 1940:47). His observation was equally true of the South Seas cases holding objects from the Black Collection (Figures 8 and 9; see Foster 2012).

The great virtue of a networked biographical approach to things is its insistence on the almost protean nature of apparently unchangeable material things. The different meanings attached to objects in the Black Collection at the different moments that I have identified are not mutually exclusive. As Kopytoff observed, "the same thing may, at the same time, be seen as a commodity by one person and as something else by another" (1986:64). The meaning of things is neither fixed nor uncontested; it inevitably exceeds the control of its makers. Put otherwise, the networks in which things become enrolled do not always respond to a single source of governance. Curio can become fine art, and vice versa. 


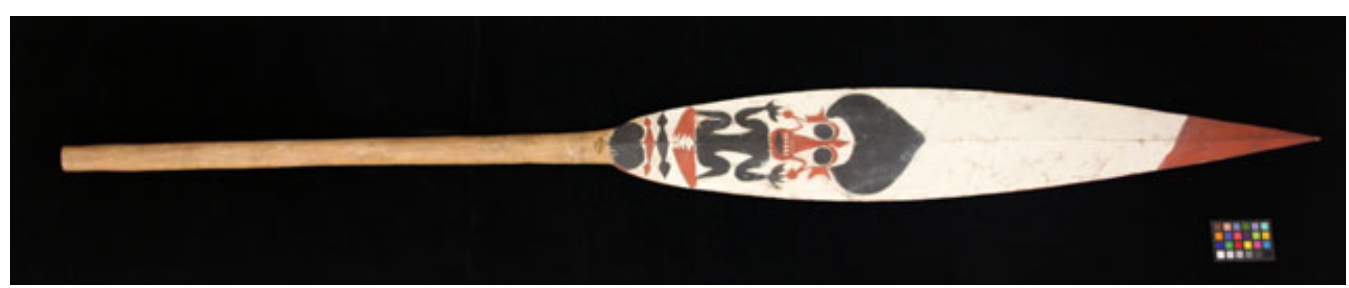

Figure 11. Canoe paddle, Buka Passage, Papua New Guinea. (Courtesy Buffalo Museum of Science.)

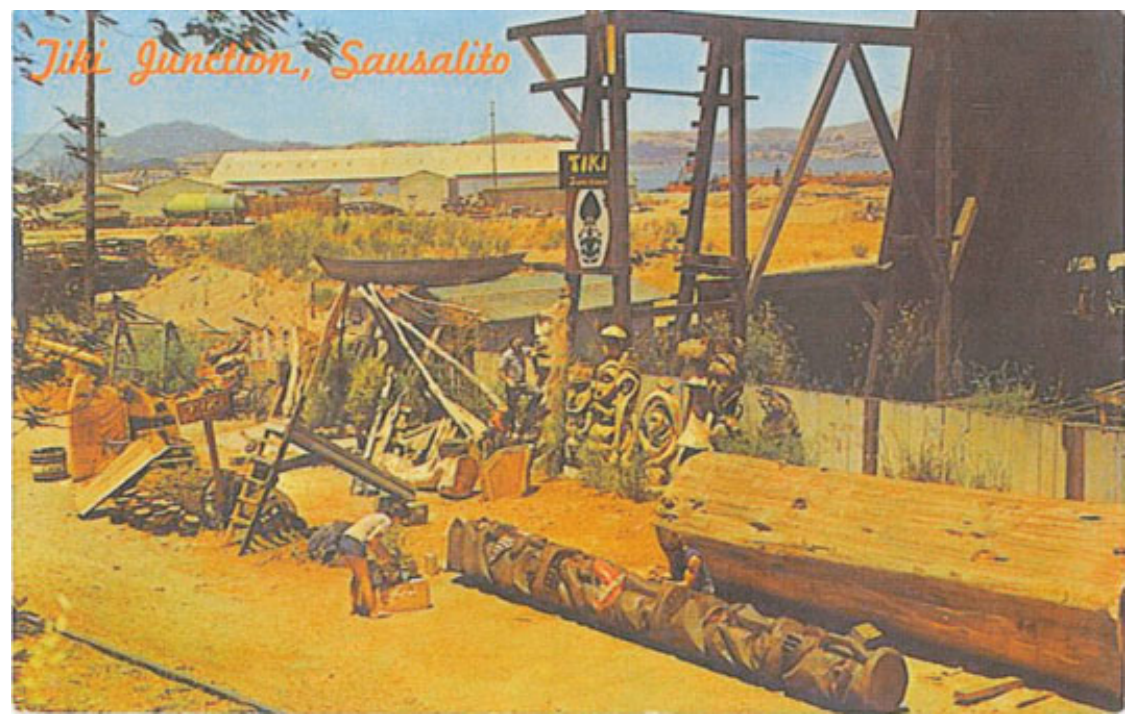

Figure 12. Postcard image of Tiki Junction, workshop of carver Barney West, circa 1965. (Source: http://www.tikiroom.com/tikicentral/bb/viewtopic.php? topic $=27808 \&$ forum $=5 \&$ start $=30$, accessed March 8, 2012.)

The fundamental instability of things is well illustrated by the complicated example of multiple creative appropriations of an incised canoe paddle from Buka that was used on the cover of the Arts of the South Seas catalogue (Figure 10). The cover image recalls the design of a paddle from Buka, Solomon Islands now held by the Peabody Essex Museum of Salem and pictured in the catalogue. That image disavows, however, a strong possibility, namely, that "Buka" canoe paddles were in the late 19th century commodities produced in bulk by Buka men working as plantation laborers in New Britain (not Buka) for the European traders Richard Parkinson and Thomas Farrell (Specht 1999:xxi). Farrell and Parkinson sold numerous paddles, along with other objects, to museums in Australia and elsewhere, where the commodities became artifacts and specimens. A paddle of similar design to the one pictured in the MoMA catalogue is now held by the Buffalo Museum of Science (Figure 11); it was acquired in 1939 by exchange with the Field Museum in Chicago for objects in the Black Collection. The paddle was originally acquired in 1908 by George Dorsey, chief curator of anthropology at the Field Museum - whether by purchase from Parkinson or by other means I cannot say for sure (see Specht 1999:xviii).

The MoMA appropriation was in turn appropriated. The design on the Buka paddle subsequently came to serve as the logo for Tiki Junction in Sausalito, California - the workshop of Barney West, a famous carver who supplied huge redwood Tiki sculptures to Polynesian-themed restaurants such as Trader Vic's across the United States and worldwide (Figure 12). The paddle decoration's commodity potential was thus reactivated in a new social and material context. Nor, of course, should we expect that Barney West's appropriation was the last. This discussion, for instance, reflexively marks another shift in the meaning of the paddle and its design. Likewise, this article marks another new moment in the unfinished biography of the P. G. T. Black Collection.

\section{ACKNOWLEDGMENTS}

Research for this article was generously supported by funds from the National Endowment for the Humani- 
ties, the American Council of Learned Societies, the Australian National University Vice-Chancellor's Travel Award for Visiting International Academics, and the University of Rochester. I am grateful for the invaluable help and warm collegiality of Kathryn Leacock, Curator of Collections at the Buffalo Museum of Science; for help with images, I am indebted to Brooke Genter, Collections Documentation Specialist. My research at the Australian Museum has been facilitated by Robin Torrence, who has supported this project with enthusiasm. I also thank Yvonne Carillo-Huffman for assistance with collections, Vanessa Finney for assistance with archival material, and Dion Peita for assistance with images. Robin Torrence and Peter White offered gracious hospitality and lively conversation during my stays in Sydney. Victoria Pass shared her own research into Arts of the South Seas and tipped me off about the Tiki Junction logo. I have benefited from ongoing conversations with Janet Berlo and Margaret Jolly, and from the thoughtful comments of many colleagues who heard presentations of earlier versions of this article at the University of Rochester; Macleay Museum, University of Sydney; Australian National University; University of Exeter; University of Pennsylvania; University of Auckland; and the Centre for Historical Research, National Museum of Australia. I thank my hosts Anne Clarke, Jude Philp, Margaret Jolly, Ian Cook, Brian Spooner, Mark Busse, and Peter Stanley. The sharp observations of Robin Torrence, the helpful references from Anne Clarke, and the reviews of two anonymous referees have improved the final version.

\section{NOTES}

1. Black usually identified himself and was referred to by others as P. G. Black; the Buffalo Museum of Science refers to his collection as the P. G. T. Black Collection.

2. A. W. F. Fuller, an Englishman who retired from military service in 1921, assembled his collection of some 72 hundred objects mainly through purchases supplemented by occasional gifts and exchanges; he never visited the Pacific Islands. Approximately fifty percent of the Fuller Collection is from Melanesia, forty percent from Polynesia, and ten percent from Australia and Micronesia. By contrast, A. B. Lewis, an American anthropologist who studied with Franz Boas, acquired more than 15,000 objects mainly through field collecting supplemented by purchases from traders, missionaries, and colonial residents who he met during his 1909 to 1913 expedition to the southwestern Pacific. Lewis's collection is the most comprehensive assemblage of objects from the islands of
Melanesia (including Fiji and the New Guinea coast) in the United States.

3. Compare the recent call by Byrne et al. for research on museum collections that considers how "over time and across space interactions between objects and a wide range of people have generated a complex assemblage of material and social networks" (2011:3).

4. For an image of a page from Black's diaries, see Smith (1995:6).

5. Mutuaga's work has turned up recently in several auction sales. In 2010, Sotheby's sold one lime spatula for US $\$ 62,500$ and another for $€ 51,500$.

6. Australian Museum Archives, Letters Received, B48/07; Black quoting Meek.

7. Australian Museum Archives, Letters Received, B48/07.

8. Thanks to Pam Swadling for this reference.

9. Buffalo Museum of Science Archives, letter to Hamlin from P. T. W. Black, July 21, 1938.

10. Australian Museum files, Department of Anthropology, P. G. Black file, 15 September 1972.

11. Wulric Black also sold ethnographic objects, including two human skulls, collected by his father to the Australian collector Melbourne Ward, presumably for inclusion in Ward's private museum, the Gallery of Natural History and Native Arts on the grounds of the Hydro Majestic Hotel in Medlow Bath, Blue Mountains. The contents of Ward's museum, including a few objects that can be traced to P. G. Black, came to the Australian Museum in 1970.

12. Grimshaw, foreshadowing Malinowski's remarks about the passion shown for shell valuables, observed on Vanatinai (Sudest Island) that: "A native will often engage in plantation or carrier work on the mainland for two years, in order to have money to purchase a pair of these ornaments [white shell armlets], which are kept by almost all traders, though they are purely of native manufacture. A fairly good pair will cost three or four pounds, and the prices range upwards from this comparatively modest sum, to the twenty or thirty pounds sometimes given by a sort of native syndicate, for a pair of really famous bracelets, known to half the Possession, and named, as all the celebrated shell armlets are" (1911:301-302).

13. Grimshaw noted in 1908 that a month's salary for a "native boy" working in the Kulumadau gold mine on Woodlark Island was ten shillings (1911:280).

14. Black did acquire at least two large objects: a large vertical slit drum from Mele Village, Efate Island (near Port Vila) in the New Hebrides (Vanuatu) and a 14-foot long canoe from 
Ngela (New Florida), Solomon Islands. He donated both to the Australian Museum. The slit drum was repatriated to the Vanuatu Cultural Centre as a gift from the Australian Museum in 1981.

15. There is at least one mourning costume in the Black Collection - a widow's bodice, cap, and breast covering decorated with Job's tears from the Oro area of southeastern Papua. Interestingly, there seems to be a similar ("duplicate"?) costume in the collection of the Field Museum, acquired by A. B. Lewis in a 1939 swap of items from the Field Museum for items in the Buffalo Museum's P. G. T. Black Collection.

16. Much of Burns's collection is now held in the Australian Museum.

17. Australian Museum Archives, AMS9, B70/22.

18. Australian Museum Archives, AMS9, B70/22.

19. Australian Museum Archives, AMS 10, 45/34. Thanks to Anna Edmundson for this reference.

20. In 1939, objects from the Black Collection were included in exchanges with the Field Museum for Melanesian objects from areas not represented in the Black Collection, and with the American Museum of Natural History and the Denver Art Museum primarily for Native American objects.

21. Niquette and Buxton (2009) suggest that the Buffalo Museum of Science grand narrative was not only evolutionist but also eugenicist.

22. A press release for the show noted: "Objects from islands and island groups that are appearing daily in war communiques dominate the collection. Among things shown are weapons, both for war and ceremonial purposes, costumes on figures, textiles, fishing tackle, paddles, games, masks, house decorations and boat models. Each section has an accompanying map of the area prepared by Dr. Herbert J. Spinden, Curator of American Indian Arts and Primitive Cultures whose department supplies the objects for the exhibition” (http://www.brooklynmuseum.org/opencollection/ exhibitions/1727/Oceanic_Art, accessed February 16, 2012).

\section{References Cited}

Alberti, Samuel J. M. M.

2005 Objects and the Museum. Isis 96(4):559-571.

Anderson, Benedict

1991 Imagined Communities: Reflections on the Origins and Spread of Nationalism. Rev. edition. New York: Verso.

Australian Museum Trust

1988 Pieces of Paradise. Sydney: Australian Museum.
Becke, Niya

1933 South Sea Curios, The World's Best Collection. Sydney Morning Herald, November 1: 12.

Beran, Harry

1996 Mutuaga: A Nineteenth-Century New Guinea Master Carver. Wollongong: University of Wollongong Press.

Burns, Philp and Company

1914 Picturesque Travel Under the Auspices of Burns, Philp \& Company Limited. No. 4. Sydney: Burns, Philp and Company.

Byrne, Sarah, Anne Clarke, Rodney Harrison, and Robin Torrence

2011 Networks, Agents and Objects: Frameworks for Unpacking Museum Collections. In Unpacking the Collection: Networks of Material and Social Agency in the Museum. Sarah Byrne, Anne Clarke, Rodney Harrison, and Robin Torrence, eds. Pp. 3-26. New York: Springer.

Clawson, H. Phelps

1941 By Their Works: Illustrated from the Collections in the Buffalo Museum of Science. Buffalo: Buffalo Society of Natural Sciences.

Clifford, James

1988 The Predicament of Culture: Twentieth-Century Ethnography, Literature and Art. Cambridge, MA: Harvard University Press.

Commonwealth of Australia

1908 Papua. Annual Report for the Year Ending 30th June 1907. Government Printer for the State of Victoria.

Duncan, Kate C.

20001001 Curious Things: Ye Olde Curiosity Shop and Native American Art. Seattle: University of Washington Press.

Etheridge, R., Jr.

1908 Ancient Stone Implements from the Yodda Valley Goldfield, North-East British New Guinea. Records of the Australian Museum 7 (1):24-28

Famous Black Collection of Artefacts

1950 Pacific Islands Monthly, October: 42.

Fforde, Cressida

2004 Collecting the Dead: Archaeology and the Reburial Issue. London: Duckworth.

Florek, Stan

2005 The Torres Strait Islands Collection at the Australian Museum. Technical Reports of the Australian Museum. No. 19. Sydney: Australian Museum. 
Force, Roland W., and Maryanne Force

1971 The Fuller Collection of Pacific Artifacts. New York: Praeger.

Foster, Robert J.

2006 Tracking Globalization: Commodities and Value in Motion. In The Sage Handbook of Material Culture. Chris Tilley, Webb Keane, Susanne Küchler, Mike Rowlands, and Patricia Spyer, eds. Pp. 285-302. London: Sage.

2012 Art/Artefact/Commodity: Installation Design and the Exhibition of Oceanic Things at Two New York Museums in the 1940s. The Australian Journal of Anthropology (TAJA) 23(2).

Geary, Christraud M.

2006 From the South Seas: Life Histories of Works in the Tell Collection. In From the South Seas: Oceanic Art in the Teel Collection. Christraud Geary, ed. Pp. 18-31. Boston: Museum of Fine Arts.

Gosden, Chris, and Frances Larson, with Alison Petch

2007 Knowing Things: Exploring Collections at the Pitt Rivers Museum 1884-1945. New York: Oxford University Press.

Gosden, Chris, and Yvonne Marshall

1999 The Cultural Biography of Objects. World Archaeology 31(2):169-178.

Gramly, Richard Michael

1988 Art and Anthropology on a Sliding Scale. In ART/artifact: African Art in Anthropology Collections. Pp. 33-40. New York: Center for African Art.

Grimshaw, Beatrice

1911 The New New Guinea. Philadelphia, PA: Lippincott.

Hamlin, Chauncey J.

1938 The Second Seventy-Five Years. In Seventy-Five Years: A History of the Buffalo Society of Natural Sciences 1861-1936. Bulletin of the Buffalo Society of Natural Sciences 18: 5-8.

Herle, Anita

1998 The Life-Histories of Objects: Collections of the Cambridge Anthropological Expedition to the Torres Straits. In Cambridge and the Torres Strait: Centenary Essays on the 1898 Anthropological Expedition. Anita Herle and Sandra Rouse, eds. Pp. 77-105. Cambridge: Cambridge University Press.

Hill, Jude

2006 Travelling Objects: The Wellcome Collection in Los Angeles, London and Beyond. Cultural Geographies 13(3):340-366.
Hinsley, Curtis M.

1992 Collecting Cultures and Cultures of Collecting: The Lure of the American Southwest, 1880-1915. Museum Anthropology 16(1): $12-20$.

King, J. C. H.

2006 W. D. Webster. In Provenance: Twelve Collectors of Ethnographic Art in England, 17601990. Hermione Waterfield and Jonathan C. H. King, eds. Pp. 55-60. Paris: Somogy éditions d'art.

Kopytoff, Igor

1986 The Cultural Biography of Things: Commoditization as Process. In The Social Life of Things: Commodities in Cultural Perspective. Arjun Appadurai, ed. Pp. 64-91. Cambridge: Cambridge University Press.

Lepowsky, Maria

2001 The Queen of Sudest: White Women and Colonial Culture in British New Guinea and Papua. In In Colonial New Guinea: Anthropological Perspectives. Naomi McPherson, ed. Pp. 125150. Pittsburgh, PA: University of Pittsburgh Press.

Linton, Ralph, and Paul S. Winegart in collaboration with Rene d'Harnoncourt

1946 Arts of the South Seas. New York: The Museum of Modern Art.

Lyons, A. P.

1950 Strange Artifacts of Old Papua. Pacific Islands Monthly, September: 59, 63.

McCarthy, Frederick D.

1938 Aboriginal Relics and Their Preservation. Mankind 2(5):120-126.

Meek, A. S.

1913 A Naturalist in Cannibal Land. London: T. Fisher Unwin.

Monckton, C. A. W.

1922 Last Days in New Guinea: Being Further Experiences of a New Guinea Resident Magistrate. New York: Dodd and Mead.

Munn, Nancy D.

1983 Gawan Kula: Spatiotemporal Control and the Symbolism of Influence. In The Kula: New Perspectives on Massim Exchange. Jerry Leach and Edmund Leach, eds. Pp. 277-308. Cambridge: Cambridge University Press.

Nagel, Charles, Jr.

1945 Foreward. In Oceanic Culture: A Survey of Pacific Island Culture Illustrative of a Special Exhibition of Oceanic Art. Walter H. Diehl, ed. 
St. Louis, MO: The City Art Museum of St. Louis.

Nelson, Hank

1976 Black, White and Gold: Goldmining in Papua New Guinea, 1878-1930. Canberra: Australian National University Press.

Niquette, Manon, and William Buxton

2009 "Sugar-Coating the Educational Pill": Rockefeller Support for the Communicative Turn in Science Museums. In Patronizing the Public: American Philanthropy's Transformation of Culture, Communication and the Humanities. William J. Buxton, ed. Pp. 153-193. Lanham, MD: Lexington Books.

O'Hanlon, Michael, and Robert L. Welsch, eds.

2000 Hunting the Gatherers: Ethnographic Collectors, Agents and Agency in Melanesia, 1870s1930s. New York: Berghahn Books.

Penny, Glenn

1998 Municipal Displays: Civic Self-Promotion and the Development of German Ethnographic Museums, 1870-1914. Social Anthropology 6 (2):157-168.

Phillips, Ruth B.

2007 The Museum of Art-Thropology: Twenty-First Century Imbroglios. RES: Anthropology and Aesthetics 52:8-19.

2009 The Mask Stripped Bare by Its Curators: The Work of Hybridity in the Twenty-First Century. Histoire de l'Art et Anthropologie. Paris: INHA/Musée du quai Branly ("Les Actes"). http://actesbranly.revues.org/336, accessed July 2, 2010.

Phillips, Ruth B., and Christopher B. Steiner, eds.

1999 Unpacking Culture: Art and Commodity in Colonial and Postcolonial Worlds. Berkeley: University of California Press.

Preston, H. B.

1905 Description of a New Species of Trachiopsis from British New Guinea. Proceedings of the Malacological Society of London 6(4):207.

Rosman, Abraham, and Paula G. Rubel

1998 Why They Collected: The History of Artifact Collecting in New Ireland. Museum Anthropology 22(2):35-49.

Schaffarczyk, Sylvia

2006 Australia's Official Papuan Collection: Sir Hubert Murray and the How and Why of a Colonial Collection. reCollections: Journal of the National Museum of Australia 1 (1):41-58.
Seligman, C. G.

1904 Note Concerning the Progress of the CookDaniels Expedition to New Guinea and the Solomon Islands. Man 4(Article 114):180-181.

1905 Further Note on the Progress of the Cook-Daniels Expedition to New Guinea. Man 5(Article 29):52-53.

1906 Notes on the Tugere Tribe, Netherlands New Guinea. Man 6(Article 42):65-67.

Shelton, Anthony Alan

2005 The Imaginary Southwest: Commodity Disavowal in an American Orient. In Les Cultures Á L'Ouevre: Rencontres en Art. Michèle Coquet, Brigitte Derlon, and Monique Jeudy Ballini, eds. Pp. 75-96. Paris: Maison des Sciences de l'Homme.

Smith, Kevin P.

1995 Piecing Together the Past: The P. G. T. Black Collection. Collections (Newsletter of the Buffalo Museum of Science-Tifft Nature Preserve) 75(4):6-7.

Smyth, J. H.

1921 The Late Mr. P. G. Black: An Appreciation. Australian Stamp Journal 12(October):153-154.

Specht, James

1999 "The German Professor": Richard Parkinson. In Thirty Years in the South Seas: Richard Parkinson. Bruno Ankermann, ed. John Dennison, trans. John Peter White, trans. ed. Pp. xv-xxxii. Honolulu: University of Hawai'i Press.

Stanley, Nick

1989 The Unstable Object: Reviewing the Status of Ethnographic Artefacts. Journal of Design History 2(2/3):107-122.

Stocking George W., Jr.

1968 Race, Culture and Evolution: Essays in the History of Anthropology. New York: Free Press.

Strathern, Marilyn

1988 The Gender of the Gift: Problems with Women and Problems with Society in Melanesia. Berkeley: University of California Press.

Sun

1926 Treasure at "Tatlow," November 14.

Sydney Morning Herald

1922 Native Races. Collection of Relics. Proffered to Museum, December 8: 8.

1923 A Vanishing Opportunity, July 5: 8.

Thomas, Nicholas

1991 Entangled Objects: Exchange, Material Culture, and Colonialism in the Pacific. Cambridge, MA: Harvard University Press. 
Thomas, Trevor

1940 Artists, Africans, and Installation. Part II. Parnassus 12(4):24-27, 47.

Torrence, Robin, and Anne Clarke

2011 "Suitable for Decoration of Halls and Billiard Rooms": Finding Indigenous Agency in Historic Auction and Sales Catalogues. In Unpacking the Collection: Networks of Material and Social Agency in the Museum. Sarah Byrne, Anne Clarke, Rodney Harrison, and Robin Torrence, eds. Pp. 29-53. New York: Springer.

Vogel, Mike

1995 Secrets of the South Pacific. Buffalo: Magazine of the Buffalo News, June 11: 6M.

Vogel, Susan

1988 Introduction. In ART/artifact: African Art in Anthropology Collections. Pp. 11-17. New York: Center for African Art.

Warner, Langdon

1939 Introduction. In Pacific Cultures. Official Catalog, Department of Fine Arts, Division of Paci- fic Cultures. Pp. 9-10. Golden Gate International Exposition, San Francisco.

Welsch, Robert L.

1998 An American Anthropologist in Melanesia: A. B. Lewis and the Joseph N. Field South Pacific Expedition 1909-1913. Honolulu: University of Hawai'i Press.

Wetherell, David

1996 Charles Abel and the Kwato Mission of Papua New Guinea, 1891-1975. Melbourne: Melbourne University Press.

Woman's Budget

1931 Dolls from Many Lands, September 9.

Young, Michael W.

2000 The Careless Collector: Malinowski and the Antiquarians. In Hunting the Gatherers: Ethnographic Collectors, Agents and Agency in Melanesia, 1870s-1930s. Michael O'Hanlon and Robert Welsch, eds. Pp. 181-202. New York: Berghahn Books. 